22. Топоров, В.Н. Балтские языки / В. Н. Топоров // Языки мира: Балтийские языки / ред. колл. : В. Н. Топоров, М. В. Завьялова, А. А. Кибрик (отв. ред.). M. : Academia, 2006. - С. 10-49.

23. Топоров, В. Н. Лингвистический анализ гидронимов Верхнего Поднепровья / В. Н. Топоров, О. Н. Трубачев // Трубачев О. Н. Труды по этимологии. Слово. История. Культура. Т. 2. - М. : Языки славянской культуры, 2009. - С. 9-382.

24. Фасмер, М. Этимологический словарь русского языка : в 4 т. Т. 3 / М. Фасмер. - М. : Прогресс, 1987. - 832 с.

25. Шувалов, П. В. Три карты Европейской Сарматии Клавдия Птолемея / П. В. Шувалов // Stratum plus. - 2013. - № 4. - С. 75-90.

26. Alföldi, A. Early Rome and the Latins / Andrew Alföldi. - Ann Arbor : University of Michigan Press, 1966. - 433 p.

27. Bezlaj, F. Etimološki slovar slovenskega jezika. Prva knjiga. A-J / F. Bezlaj. Ljubljana : Institut za slovenski iezik, 1977. - $235 \mathrm{~s}$.

28. Walde, A. Lateinisches etymologisches Wörterbuch / A. Walde. - Heidelberg : Karl Winter's Universitatsbuchhandlung, 1910. - 870 s.

Стаття надійшла 28.04.2016 року

УДК $811.161 .2 ’ 282$

Тетяна Тищенко

(Умань, Украӥна)

\title{
СПОСОБИ НОМІНАЦІЇ У ТВАРИННИЦЬКІЙ ЛЕКСИЦІ СХІДНОПОДІЛЬСЬКИХ ГОВІРОК УКРАЇНСЬКОЇ МОВИ
}

У статті на матеріалі говірок східноподільського ареалу украӥнської мови проаналізовано способи номінації у твариннищькій лексиці. Зауважено, щзо основними способами номінації реалій тваринництва в східноподільських говірках української мови $\epsilon$ семантична трансформація, афіксальна деривація, композитивне словотворення, фразотворення. Аналіз тваринницької лексики засвідчив, щзо найпродуктивнішим способом словотворення $\epsilon$ суфіксація. Найчастотнішою суфіксачія $\epsilon$ у лексико-семантичній групі назв тварин, де тісно пов'язані диференційні ознаки 'вік' та 'розмір'. Продуктивним способом словотворення в досліджуваних говірках є осново- $і$ словоскладання, які на формально-словотвірному рівні представлені у вигляді чистого основоскладання, складно-суфіксального основоскладання, словоскладання, словотвірної контамінації. У всіх лексикосемантичних групах відзначено значну кількість полікомпонентних номінацій реалій тваринництва. Вони мають переважно структуру атрибутивних словосполучень.

Ключові слова: номінаційні прочеси, способи номінації, східноподільські говірки украӥнської мови, тваринницька лексика, семантична трансформація, афіксальна деривація, композитивне словотворення, фразотворення.

Тищенко Т. Способы номинации в жсивотноводческой лексике восточноподольских говоров украинского языка. 
В статье на материале говоров восточноподольского ареала украинского языка проанализированы способы номинации в животноводческой лексике. Отмечено, что основными способами номинации реалий жсвотноводства в восточноподольских говорах украинского языка является семантическая трансформаџия, аффиксальная дериваџия, композитивное словообразование, фразобразование. Анализ животноводческой лексики показал, что самым распространенным способом словообразования является суффиксация. Наиболее частотна суффиксация $в$ лексико-семантической группе названий животных, в которой тесно взаимосвязань дифференциальные признаки 'возраст' и 'размер'. Продуктивным способом словообразования в исследуемых говорах является также осново- и словосложение, которые на формально-словообразовательном уровне представлень в виде чистого основосложения, сложносуффиксального основосложения, словосложения, словообразовательной контаминации. Во всех лексико-семантических группах отмечено значительное количество поликомпонентных номинаций реалий животноводства. Они имеют преимущественно структуру атрибутивных словосочетаний.

Ключевые слова: номинационные процессы, способы номинации, восточноподольские говоры украинского языка, животноводческая лексика, семантическая трансформация, аффиксальная деривачия, композитивное словообразование, фразообразование.

Tyshchenko T. Methods of nomination in livestock vocabulary of the Eastern Podillia dialects of the Ukrainian language.

The article analyzes the main ways of nomination in livestock vocabulary on the material of the Eastern Podillia dialects of the Ukrainian language. It was established that the main ways of nomination the livestock realities in the Eastern Podillia dialects were the semantic transformation, affixal derivation, composite word building and phrase creation.

The authors determined that the nominee formed by univerbation were semantically caused by internally motivated lexical-semantic transformation. In the lexical-semantic group univerbs have been recorded to indicate poultry, they are used in parallel with attributive phrases, with the help of which they are formed.

The analysis of the livestock vocabulary showed that the most productive way of word formation were suffixes. Suffixes are most frequent in the lexical-semantic group of the animals' names where differential features of 'age' and 'size' are closely related.

Productive ways of word formation in the studied dialects are stem and word compositions which are presented on the formal word building level as pure stem composition, composite suffix stem composition, word composition, word creative contamination. A significant number of multicomponent nominations of livestock realities are noted in all lexical-semantic groups. They have mainly the structure of attributive phrases. Double word nomination expressed by free phrases is often presented in the lexical-semantic group to describe animals, including various differential features (size, age, location, physiological state).

Keywords: nomination processes, methods of nomination, the Eastern Podillia dialects of the Ukrainian language, livestock vocabulary, semantic transformation, affixal derivation, composite word building and phrase creation.

Постановка наукової проблеми та їі значення. Одним із завдань дослідника номінаційних процесів є вивчення способів та засобів номінації 
у досліджуваній тематичній групі лексики. Лексика української мови неоднаково представлена як за регіонами, ареалами побутування діалектної мови, так і набором лексико-семантичних, тематичних груп, та повнотою відтворення елементів у межах цих об'єднань. Це стосується, зокрема, і лексики тваринництва - одного 3 важливих господарських занять, що існували в Україні з давніх-давен. Різні сегменти тематичної групи представлені в дескриптивних та лінгвогеографічних працях [1;2; 4-7; 10-12; 14-16; 19; 20 та ін.].

Аналіз останніх досліджень і публікацій. Тваринницька лексика Поділля докладно вивчена лише на його північно-західному ареалі в дисертаційному дослідженні В. Шеремети «Південноволинськоподільське діалектне порубіжжя (за матеріалами тваринницької лексики») [19]. Для забезпечення надійної емпіричної бази Словника українських говорів і повнішого представлення лексики Поділля в його реєстрі нам видається актуальним системна фіксація назв тваринництва, з'ясування принципів і способів номінації у східноподільських говірках. Східноподільськими називаємо говірки, які знаходяться на території західних районів Черкаської, північно-західних Кіровоградської, східних Вінницької областей України.

У складі тематичної групи лексики тваринництва у східноподільських говірках чітко виокремлюються лексико-семантичні групи на позначення свійських тварин і птахів, вигуків, пов' язаних із підкликанням чи відгоном тварин чи птахів, приміщення для утримування птахів і тварин, людей, які працюють коло тварин. Кожна із груп має свої особливості номінації, принципи та способи.

Мета і завдання статті. У цій статті розглянемо способи номінації, найбільш виразні в названій тематичній групі лексики.

Виклад основного матеріалу й обгрунтування отриманих результатів дослідження. Спосіб номінації - це сукупність технічних засобів мови (діалекту), за допомогою яких здійснюється акт номінації тієї чи іншої реалії навколишньої дійсності, прийом реалізації принципів номінації, представленого тією чи іншою мотиваційною ознакою [17, с. 78]. Лексика тваринництва - сегмент конкретної лексики, а тому з'ясування способів номінації реалій тваринництва засвідчить загальні тенденції в номінації конкретної лексики у східноподільському ареалі української мови.

Використання власних мовних ресурсів 3 метою створення номінативної одиниці може здійснюватися двома шляхами: шляхом надання готовій номінативній одиниці нової семантичної функції (семантична трансформація) і шляхом створення формально нової одиниці (деривація, композитивне словотворення та фразотворення). Основними способами номінації реалій тваринництва у східноподільських говірках $€$ 
семантична трансформація, афіксальна деривація, композитивне словотворення, фразотворення.

Семантична трансформація слова відбувається зі зміною його синтаксичної функції або без неї, що спричинює поділ їі на різновиди: лексико-семантичний та семантико-синтаксичний $[18$, с. 53]. У досліджуваних нами говірках серед тваринницької лексики відзначено як номінаційний процес внутрішньо мотивовану та внутрішньо немотивовану лексико-семантичну трансформацію.

Парадигматично зумовленої внутрішньо мотивованої лексикосемантичної трансформації зазнали номени, що розширили чи звузили значення або метафоризувалися.

Розширення значення - лексико-семантична трансформація слова, що базується на вертикальних зв'язках між членами однієї лексикосемантичної парадигми та призводить до збільшення семантичного обсягу слова [17, с. 81]. Розширення значення слова спостережено для лексем, утворених за моделлю 'орган тварини' $\rightarrow$ 'тварина': 'мимка 'зіпсована

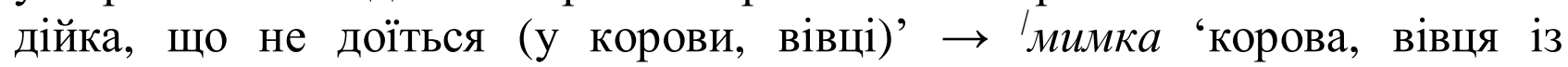
зіпсованою однією дійкою’.

Метафора - лексико-семантична трансформація слова, що базується на міжпарадигматичних зв'язках слів та виявляє себе як уживання замість одного слова іншого, яке належить до іншої лексико-семантичної парадигми, але має спільний 3 першим словом семантичний елемент диференційну або конотативну сему [18, с. 60; 17, с. 84]. Спостережено такі типові семантичні моделі: 'плід рослини' $\rightarrow$ 'результат життєдіяльності тварини': йаг їا'кu, бараболики (у досліджуваних говірках бараболька дрібна картопля), 'б iб, го'рох, го'рошок, бубки 'бібки, овечий послід';

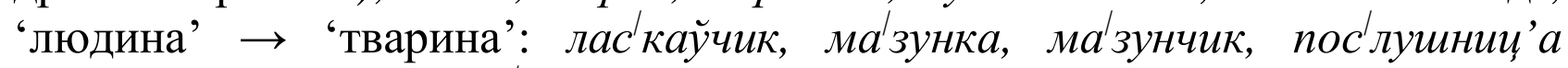
'корова слухняна'; пок'ритка 'вівця, яка рано виявила статеву охоту', 'цүиган 'кінь чорної із синюватим полиском масті'; 'зб. люди' $\rightarrow$ 'зб. тварини': гро|мада 'череда корів приватних власників'; ‘тварина' $\rightarrow$ 'тварина, яка загалом подібна до цієї тварини': nalu’'yк 'криса, шкідливий ссавець родини мишоподібних, значно більший за мишу' $\rightarrow$ nalu’'yк 'дуже маленьке поросятко’.

Наслідком семантично зумовленої внутрішньо мотивованої лексикосемантичної трансформації $\epsilon$ номени, утворені шляхом універбації. У лексико-семантичній групі на позначення свійських птахів зафіксовано універби, які вживаються паралельно 3 атрибутивними словосполученнями, на основі яких вони утворені: жнивовики ๘

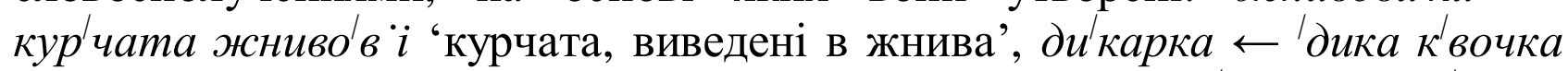
'квочка, яка вивела курчат без відома людей', $n$ 'iзн'y'p' $i \leftarrow$ курчата

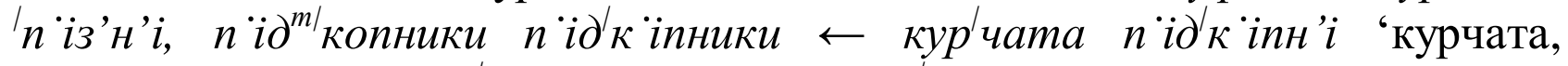
виведені в жнива', во рончик $\leftarrow$ ‘iн' вороний 'кінь чорної із синюватим 
полиском масті'; годо'вик $\leftarrow$ бичок годо'виц 'бичок річний', гн ‘ì $\kappa$ 'ін' гн 'il $и и ̆$ 'гнідий кінь'.

Творення нових слів за допомогою афіксів чи без них від існуючих основ за словотворчими моделями $є$ деривацією. Назви тваринництва мають широкий інвентар афіксальних морфем, проте їх активність не однакова.

Афіксальна деривація. Аналіз тваринницької лексики засвідчив, що найпродуктивнішим способом словотворення $є$ суфіксація. Це підтверджує спостереження $\quad$ I. В. Гороф'янюк ще над однією групою конкретної лексики - мікологічною - в центральноподільському ареалі [3, c. 92] та нашими спостереженнями над рибальською лексикою в східноподільських говірках української мови. Проте для кожної 3 досліджуваних лексико-семантичних груп характерний власний набір афіксів.

Суфіксація $\epsilon$ найчастотнішою в лексико-семантичній групі назв тварин, де тісно пов'язані диференційні ознаки 'вік' та 'розмір' передано однослівними номенами, похідними від основ, найчастіше назв тварин, за допомогою демінутивних афіксів: -ец': каба'неи' 'кабан до року',

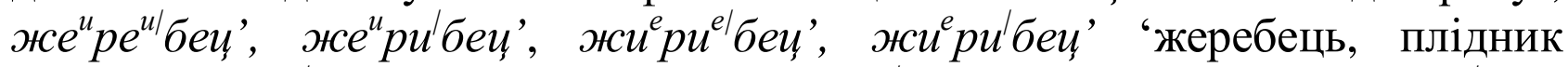
кобили', бара'неu' 'молодий баран', табу'неи' 'табун лошат', стригу'неи' 'жеребчик', сосунеи' 'маля, яке годується молоком матері', 'молочне

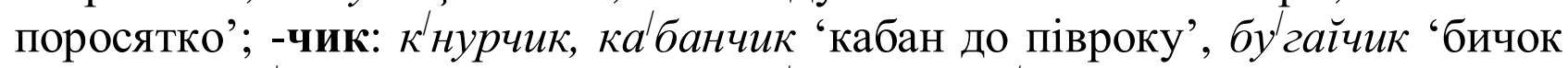
до року', ба франчик 'маля вівці', лас каўчик, ма

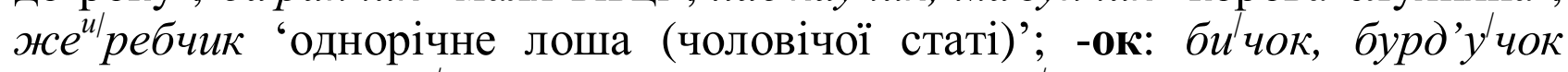
'бичок річний', буга йок 'бичок двохрічний', валу'шок 'молодий баранець', гур ${ }^{\prime}$ ток 'невелике стадо великої рогатої худоби', байструч'ки, байстр'уч'ки 'курчата, виведені квочкою без відома людей'; -ик: |n “іуник 'молодий півень, якого вже можна різати'; -ечок: бичечок 'бичок річний'; -к: годо'вичка 'телиця до одного року', гусе $e^{u \mid}$ 'атко 'пташа гуски',

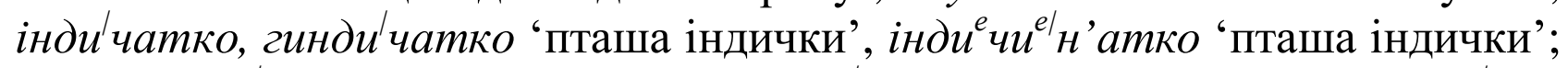

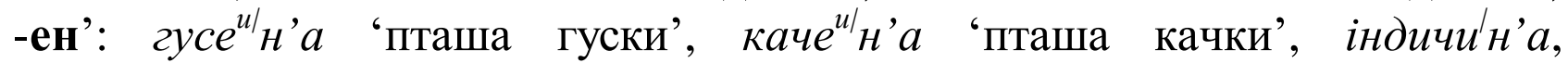
гиндичи'н'а 'пташа індички' та афіксів згрубілості чи нейтральних, які $€$

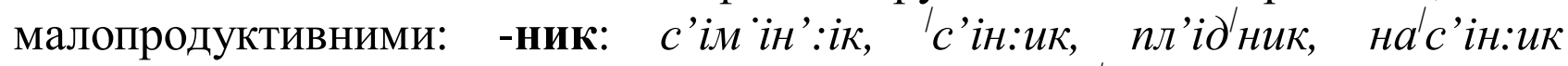
'дорослий качур, залишений на розплід', p'іч)ник 'бичок річний', пл'ім'il $н: u \kappa, \quad п л e^{u} м \ddot{i}_{н: u \kappa}$ 'кабан, бугай, баран, качур, залишені для розплоду', йал ‘йник 'стадо недійних корів', росn'л'іник 'качур на насіння'; -иц’ мо лочнии'а 'корова, яка дає багато молока', йадниц'а 'дійна вівця', годо' вии'а 'телиця річна', йаво лии'а 'корова, яка не дає потомства', кро лич'а, коро лич'а 'самиця кроля', кобилиц'а 'кобила непарована', ко зии'а 'коза ялова'; -ок: 'виводок 'виведені за один раз квочкою'; -ук:

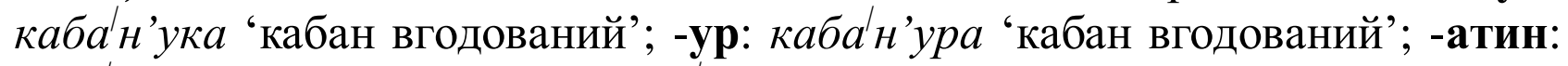

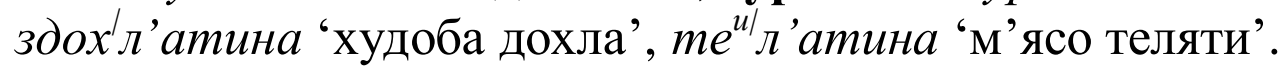


Для лексико-семантичної групи агентивів характерні форманти -ик, -ник, -шчик та -яр: гурто'вик 'доглядач стада худоби', воли'вик, волоўник, волоўшчик 'той, хто доглядав волів', за'б їйник, ' р їшник, 'бойшчик, мн'ас'ник, 'бойшч'ік, за'б'ійшчик, за бойшчик, у'бойшчик

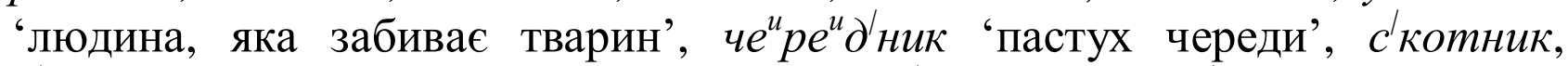
скотн'ік 'людина, яка доглядає бичків', c'maдник, стадник 'доглядач за

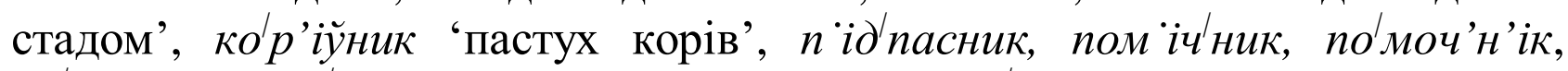
по мошн'ік, по'мошник 'помічник пастуха', о' тарник 'старший чабан', mа'буншчик, та'бунник 'конепас'; во л'ар, во лар 'той, хто доглядає волів', 'дойар 'чоловік, який доїть корів, овець, кіз', ко дар, ко'н'ар 'конепас', cви'нар 'пастух свинячий', ско'тар 'пастух колгоспної худоби', коз зар, |коз'ар 'пастух кіз', ко'л'ар 'чоловік, який коле свиней'.

Лексико-семантичну групу на позначення приміщення для тварин формують репрезентанти, утворені за допомогою суфікса -ник: курник 'окрема будівля для утримання курей в умовах домашнього господарства',

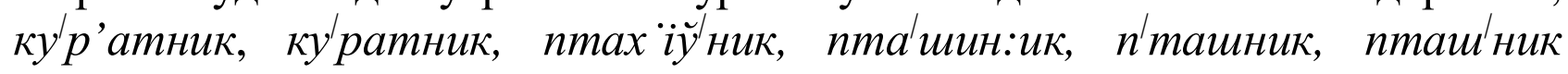
'громадська будівля чи власність одного господаря житла для птахів', ' маточник 'підсобне приміщення для утримування свиней взимку', сви'нарник 'громадська будівля для утримування свиней', в їўчарник, ойччарник, оўччарн'ік 'громадська будівля для розведення овець', голуб̆йатник 'будівля для розведення голубів', зи м “йник 'громадське приміщення для утримування корів узимку', кор'ўник, корроўн'ік, корроўник 'громадська будівля для утримування корів', крол'їуник, крол'ї̆ник 'приміщення для розведення кролів'.

Малопродуктивними в утворенні лексики тваринництва $\epsilon$ префіксальний та префіксально-суфіксальний способи, зокрема зафіксовано префіксальні деривати $n$ 'ідломак 'жеребець до року',

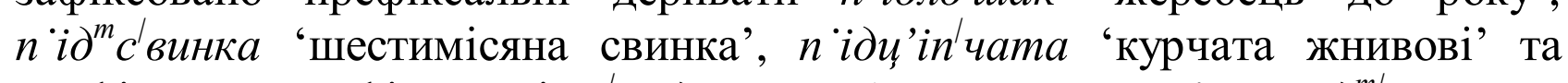

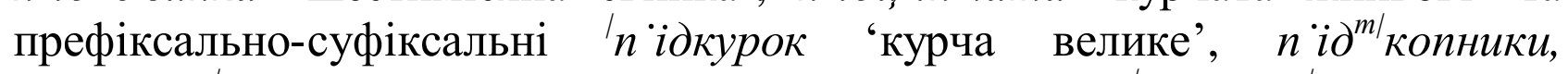

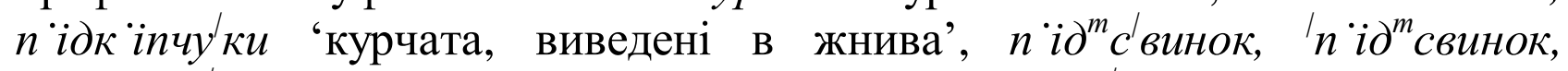

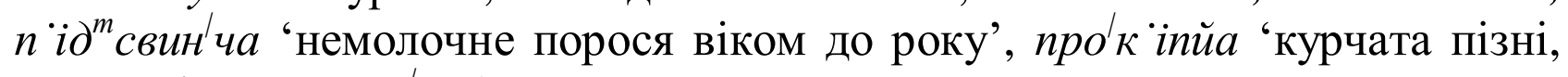
виведені в жнива', I $n$ “дкурок 'курча велике'.

Безафіксальна дериваџія. У лексико-семантичних групах на позначення місця, пов'язаного 3 тваринництвом, та результатів господарювання зафіксовано репрезентанти, утворені безафіксним

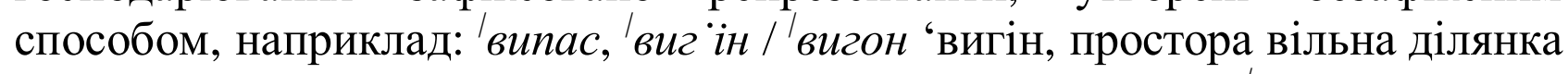
біля села або в селі, куди виганяють пасти худобу', в ‘ì ходи 'залишки неперетравленої їі', до д’ $i \check{\imath}$ 'процес видоювання решти молока', $n e^{u} p e^{u \mid} \partial о \check{\imath}$

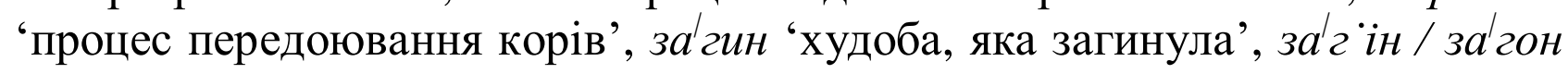
'огороджене місце, куди заганяють тварин на відпочинок чи ночівлю влітку або щоб хазяйки мають можливість їх подоїти', ।загорода 'відгороджене місце у сараї для свиней', знак 'мітка, яка вказує на 
належність тварини хазяїну в загальному стаді або на їі якісь особливості',

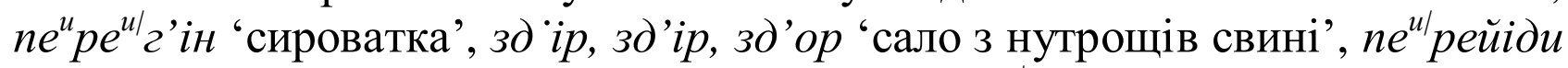
'недоїдені тваринами залишки грубих кормів', 'поклад 'поклад, яйце, яке кладеться в певному місці, щоб курка там неслася'.

Композитивне словотворення. Дослідники номінаційних процесів сучасної української мови зауважують, що продуктивним способом словотворення української мови є осново- і словоскладання, застосування яких на всіх етапах іï розвитку сприяло поповненню словникового складу $[13$, c. 83$]$.

На формально-словотвірному рівні семантична композиція представлена у вигляді:

а) чистого основоскладання: кроле фиерма 'ферма, на якій розводять

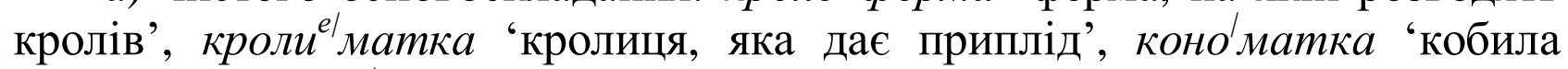
жеребна', ве 'тра'ботн' $і к$ 'ветеринар';

б) складно-суфіксального основоскладання: ското могил'ник 'худоба дохла', само с'едка 'квочка, яка сіла на яйця без відома людей', одно годка

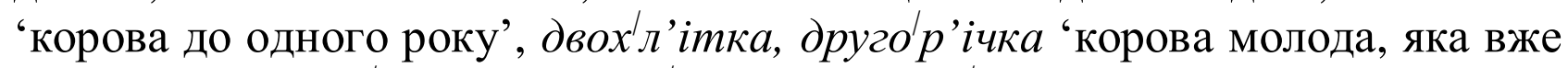
телилася', друго'т’ілка, друго|родка, ўторо родка 'корова, яка вдруге народила'.

Різновидом складно-суфіксального основоскладання $є$ складнонульовий спосіб (основоскладання завершується нульовою суфіксацією): ме ртвород 'плід мертвонароджений', козо'nac 'той, хто пасе кіз', коне| nac 'людина, яка пасе коней', гурто' прай 'чабан старший';

в) словоскладання: 1) 3 атрибутивними відношеннями між компонентами: ко за-йало'вuи'a 'коза, яка жодного разу не давала потомства', кнур-запл·ідник 'кабан-плідник', курччата-байстр'уччата 'курчата, виведені квочкою без відома людей', ло иак-каст ратор 'кінь кастрований', те ли лич’а-йал “йка 'корова, яка ще не парувалась', 'л’оикаI $п$ ітсвинок 'свиня до року'; 2) сурядними відношеннями між компонентами: 'курка-Іn івен' 'курка-гермафродит', 'йанчики-ба'ранчики 'стадо ягнят';

г) словотвірної контамінації, зокрема телескопічного словотворення,

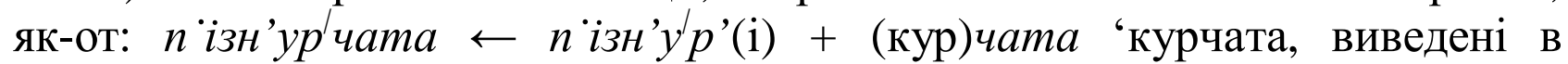
жнива'.

Осново- i словоскладання як номінаційний процес найбільш характерний для лексико-семантичних груп на позначення тварин та агентивів.

Фразотворення. У всіх лексико-семантичних групах відзначено значну кількість полікомпонентних номінацій реалій тваринництва. Вони мають структуру переважно атрибутивних словосполучень. Двослівну номінацію, виражену вільними словосполученнями, найчастіше представлено в лексико-семантичній групі на позначення тварин, зокрема 
за різними диференційними ознаками (розміром, віком, місцем знаходження, фізіологічним станом): ко'рова сu'pa 'корова, яка щойно отелилася', ко рова не строккова 'корова, яка раніше терміну народила маля', ко'рова до'ходна 'корова, яка привела двійню', ко рова у о хотн' $i$ 'корова, яка виявляє статеву охоту', ко рова бе з рогів', корова $y^{\prime}$ 'ол'на 'корова, яка щойно отелилася', корова не пок'рита 'корова, яка не погуляла', ко'рова з | танжом 'корова, яка доїться на три дійки' та ін. Зрідка виявлено номінативні словосполучення за моделлю сурядного словосполучення, що мають більш яскраве емоційне забарвлення, ніж синонімічна однослівна назва $\mu^{\prime} i$ n $\ddot{i}^{\prime} m y x$ i $\mu^{\prime} i$

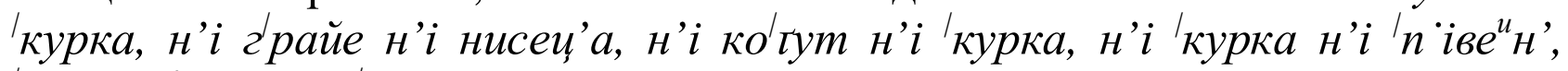
|курка й'n 'івин' ўмест “ 'курій, курка-гермафродит'.

Особливістю полікомпонентних номінацій тваринництва є утворення ïx на основі повторення кореневих морфем чи оксюморону: уррач

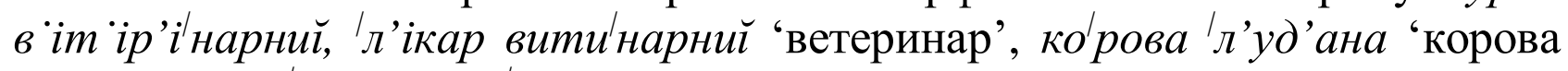
слухняна', 'волух нечишчениц 'баран плідний' (валах - баран кастрований).

Висновки та перспективи подалышого дослідження. Отже, у східноподільських говірках виявлено різні способи номінації реалій тваринництва: основними $\epsilon$ семантична трансформація слова, деривація, композитивне словотворення та фразотворення. Такий поділ є умовним, оскільки наявні комбіновані способи номінації, наприклад метафора 3 деривацією, складно-суфіксальне основоскладання. Продуктивність різних способів словотворення не однакова. Найпродуктивнішими $\epsilon$ лексико-семантичний спосіб та морфологічний суфіксальний словотвір. Композитивне словотворення як перехідне явище від однослівної до багатослівної номінації здійснюється шляхом чистого основоскладання, складносуфіксального основоскладання, словоскладання. Словотворчі форманти як засоби номінації реалій тваринництва характеризуються різним ступенем продуктивності. Найпродуктивнішими формантами $\epsilon$ суфікси.

Полікомпонентні номени за структурою $\epsilon$ атрибутивними словосполученнями, частина з яких зазнає універбації.

Вивчення способів номінації у тваринницькій лексиці східноподільського ареалу окреслило основні тенденції номінації в групі лексики з конкретним значенням і спонукає до дослідження подібних тематичних груп.

\section{СПИСОК ВИКОРИСТАНОЇ ЛІТЕРАТУРИ}

1. Бухтий, Н. В. Овцеводческая лексика говоров Херсонщины : автореф. дис. на соискание ученой степени канд. филол. наук : спец. 10.02.01 «Украинский 
язык» / Н. В. Бухтий. - Днепропетровск, 1991. - 19 с.

2. Герман, К.Ф. К вопросу о развитии пастушеской терминологии в славянских язиках (наименование самца овцы) / К.Ф.Герман // Общеславянский лингвистический атлас: Материалы и исследования. 1977. - М. : Наука, 1979. C. $37-45$.

3. Гороф'янюк, I. B. Способи номінації в мікологічній лексиці центральноподільських говірок / І. В. Гороф'янюк // Мовознавчий вісник : зб. наук. пр. / МОН України. Черкаський нац. ун-т ім. Б. Хмельницького ; відп. ред. Г. І. Мартинова. - Черкаси, 2009. - Вип. 9. - С. 89-100.

4. Гриценко, П.Е. Генезис и семантическая структура сельскохозяйственной лексики украинских западностепных говоров : автореф. дис. на соискание ученой степени канд. филол. наук : спец. 10.02 .02 «Украинский язык» / П. Е. Гриценко. - К., 1980. - 29 с.

5. Гриценко, П. Ю. Діалектна лексика з конкретним значенням / П. Ю. Гриценко // Структурні рівні українських говорів. - К. : Наук. думка, 1985. - С. 91-121.

6. Гриценко, П. Ю. Дослідження лексики українських говорів / П. Ю. Гриценко // Мовознавство. - 1984. - № 5. - С. 22-30.

7. Гриценко, П. Ю. Моделювання системи діалектної лексики / П. Ю. Гриценко. К. : Наук. думка, 1984. - 227 с.

8. Гриценко, П. Ю. Структурна організація назв свійських тварин (на матеріалі західностепових говірок) / П. Ю. Гриценко // Мовознавство. - 1980. - № 2. C. $48-57$.

9. Гриценко, П. Ю. Тваринницька лексика українських західностепових говірок. Питання організації тематичної групи / П. Ю. Гриценко // Структура українських говорів. - К. : Наук. думка, 1982. - С. 142-170.

10. Дзендзелевский, И. А. Овцеводская лексика закарпатських говоров / И. А. Дзендзелевский // Общеславянский лингвистический атлас: Материалы и исследования. - М. : Наука, 1965. - С. 122-123.

11. Карпова, В. Л. Назви тварин та слова на означення пов'язаних з ними понять у мові пам'яток XIV - XV ст. / В. Л. Карпова // Питання історії української мови. - К. : Наук. думка, 1970. - С. 26-52.

12. Клепикова, Г. П. Славянская пастушеская терминология: еe генезис и распространение в языках карпатского ареала / Г. П. Клепикова. - М. : Наука, 1977. - C. 162-188.

13. Клименко, Н. Ф. Осново- і словоскладання у процесах номінації сучасної української мови / Н. Ф. Клименко // Українська мова. - 2003. - № 3-4. - С. 83105.

14. Куриленко, В. М. Атлас лексики тваринництва у поліських діалектах / В. М. Куриленко. - Глухів, 2004. - 260 с.

15. Куриленко, В. М. Лексика тваринництва поліських говорів / В. М. Куриленко. Суми : Мрія, 1991. - 87 с.

16. Пуйо, И. Ю. Скотоводческая лексика украинских говоров района Карпат : автореф. дис. на соискание научной степени канд. филол. наук : спец. 10.02.02 «Украинский язык» / И. Ю. Пуйо. - К., 1981. - 24 с.

17. Скорофатова, А.О. Ономасіологія та лінгвогеографія фітономенів в українських східнослобожанських говірках : монографія / Анна Олександрівна Скорофатова. - Луганськ : Елтон-2, 2009. - 369 с. 
18. Способы номинации в современном русском языке / Д.Н. Шмелев, А. Ф. Журавлев, О. П. Ермакова и др.; отв. ред. Д. Н. Шмелев. - М. : Наука, 1982. - 296 c.

19. Шеремета, Н. П. Південноволинсько-подільське діалектне порубіжжя (за матеріалами тваринницької лексики) : дис. ... канд. філол. наук : 10.02.01 / Шеремета Наталія Петрівна. - Кам’янець-Подільський, 2000. - 321 с.

20. Ястремська, Т. О. Структурно-семантична організація та географічна диференціація пастушої лексики гуцульського говору : автореф. дис. на здобуття наукового ступеня канд. філол. наук : спец. 10.02 .01 «Українська мова» / Т. О. Ястремська. - К., 2002. - 19 с.

Стаття надійшла 10.03.2016 року

УДК 811.161.2’38:821.161.2

Олександр Черевченко, Вікторія Черевченко

(Умань, Украӥна)

\section{ЛІНГВОСТИЛІСТИЧНЕ МОДЕЛЮВАННЯ ПОЕТИЧНОГО ТЕКСТУ УКРАЇНСЬКОГО НЕОКЛАСИЦИЗМУ}

Статтю присвячено дослідженню особливостей лінгвостилістичного моделювання поетичного тексту, виявленню функціонально-мовних закономірностей y поезї. У роботі визначено егоцентричні особливості поетичного мовлення, проаналізовано специфіку поетичного висловлювання. Лексична система характеризується використанням різних груп лексики як за походженням (народнорозмовна, старослов'янська, діалектна, просторічна, запозичена), так $i$ за тривалістю перебування та місием у мовній системі (архаїчна, індивідуальноавторська, історично та культурно маркована). Дослідження ідіостилів поетівнеокласиків дало можливість виявити універсальне та специфічне в поетичному мовленні як моделі комунікації.

Ключові слова: поетичний текст, мовна картина світу, поетичний дискурс, ідіостиль, образно-символічна паралель.

\footnotetext{
Черевченко А., Черевченко В. Лингвостилистическое моделирование поэтического текста украинского неоклассицизма.

Статья посвящена исследованию особенностей лингвостилистического моделирования поэтического текста, определению функиионально-языковых закономерностей в поэзии. В работе определень эгочентрические особенности поэтической речи, исследована специфика поэтического выражения. Лексическая система характеризуется использованием различных групп лексики по происхождению (разговорная, старославянская, диалектная, просторечная, заимствованная) и временем существования в языковой системе (архаическая, индивидуально-авторская, исторически и культурно маркированная). Исследование идиостилей поэтов-неоклассиков дало возможность определить универсальное и специфическое в поэтической речи как модели коммуникации.
} 